\title{
AZ IROTA KÖRNYÉKI VEZETÖKÉPESSÉG ANOMÁLIA KOMPLEX GEOFIZIKAI ÉRTELMEZÉSE
}

\author{
Nádasi Endre \\ tanársegéd, Miskolci Egyetem, Geofizikai és Térinformatikai Intézet, Geofizikai Tanszék \\ 3515 Miskolc, Miskolc-Egyetemváros, e-mail: gfne@uni-miskolc.hu
}

\begin{abstract}
Absztrakt
A Cserehát területén Irota és Gadna települések közelében szulfidos ércesedésre utaló indikációk ismertek. Az ércesedési zóna lehatárolása érdekében magnetotellurikus (MT) mérések történtek, melyek vezetóképesség anomália jelenlétét igazolták. Az anomália csak a korábbi kutatásokhoz kapcsolódó egyéb geofizikai módszerek mérési eredményeivel, illetve földtani észleléseivel összevetve értelmezhetö biztonsággal. Az erőtér-geofizikai módszerek gravitációs és mágneses anomáliákat tártak fel, míg a szeizmika fontos szerkezeti elemek, leginkább vetök jelenlétét igazolta a területen. Az MT mérések $2 D$ és $3 D$ inverziós feldolgozása is megtörtént. Jelen tanulmány célja a különbözö felszini geofizikai mérésekböl származó információk szintetizálása.
\end{abstract}

Kulcsszavak: magnetotellurika, gravitáció, mágnesség, anomália, értelmezés

\begin{abstract}
In the Cserehát region (NE Hungary), in the vicinity of Irota and Gadna villages an indication of sulfide mineralization is well-known. In order to delineate the ore mineralization, magnetotelluric (MT) measurements were performed which proved the presence of conductive anomaly. This anomaly can only be interpreted reliably with the survey results of other geophysical methods. The potential field methods demonstrated gravity and magnetic anomalies, the seismic survey pointed out important structural elements, mainly faults. The MT data were processed by $2 D$ and $3 D$ inversion techniques as well. The aim of this study is the synthesis of information which originate from different surface geophysical methods.
\end{abstract}

Keywords: magnetotellurics, gravity, magnetics, anomaly, interpretation

\section{Bevezetés}

Az Északkelet-Magyarországon található Cserehátban, a Szendrői-hegységtől délkeletre, Irota, Gadna és Felsővadász települések között található ércesedés a XX. század közepe óta ismert. Az alábbiakban a geofizikai mérések szempontjából kerül összefoglalásra a terület kutatástörténete, valamint az egyes mérésekből származó anomáliák térképi összevetése is bemutatásra kerül.

A Magyar Állami Eötvös Loránd Geofizikai Intézet a medencealjzat mélységének térképezése céljából végzett geofizikai méréseket az egész Cserehát területén. Az '50-es és '60-as években földmágneses, 1964-ben pedig komplex (VESZ, tellurikus, szeizmikus) geofizikai kutatást végeztek. Ez utóbbiak a Szendrői-hegység területére is kiterjedtek. A geomágneses mérések alapján jelentős anomáliákat fedeztek fel, melyek elszórva jelentkeztek a Cserehát egész területén (irotai, selyebi, büttösi mágneses anomáliák) [1]. 
Tellurikus anomália Alsóvadász térségében jelentkezett, ahol a szeizmikus reflektáló felület mélységében a geoelektromos mérések nem mutattak nagy ellenállású képződményt. Ezt a megállapítást az Alsóvadász-1 jelủ fúrás igazolta, ugyanis a megadott mélységben az aljzat kis fajlagos ellenállású, de nagy hullámterjedési sebességü sötétszürke agyagpala és kovapala [2]. További geofizikai mérések az 1980-as évek közepén történtek [1].

A Cserehát dombvidékén 1967-69 között a Mecseki Ércbányászati Vállalat végzett uránkutatást. Több fúrásban is jelentkeztek erősen szulfidos (pirrhotinos, pirites, kalkopirites, szfalerites) szakaszok, ezt később az 1988-ban a MÁFI (Magyar Állami Földtani Intézet) által mélyített Felsővadász-1 fúrás is igazolta. A Cserehát előkutatását az ELGI (Eötvös Loránd Geofizikai Intézet) kezdte meg az 1980as évek derekán, mivel a terület nyersanyag perspektívája meglehetősen ismeretlen volt [1].

A 2010-es évek elején a Miskolci Egyetem Ásványtani-Földtani Intézete és a Rotaqua Kft. kezdett kutatásokba a területen. Majd a Miskolci Egyetem által vezetett CriticEl projekt egyik célterülete volt az Irota környéki ércesedés. A korábban megismert színesfém dúsulás és grafit jelenléte mellett a legújabb kutatások a platinacsoport fémeire, valamint a ritkaföldfémekre is kiterjednek [3].

\section{Földrajzi elhelyezkedés és földtani háttér}

A tanulmányban vizsgált terület az észak-magyarországi Cserehátban található. Irota és Gadna települések a Szendrői-hegység délkeleti határán húzódnak. A terület átlagos tengerszint feletti magassága 250-300 méter.

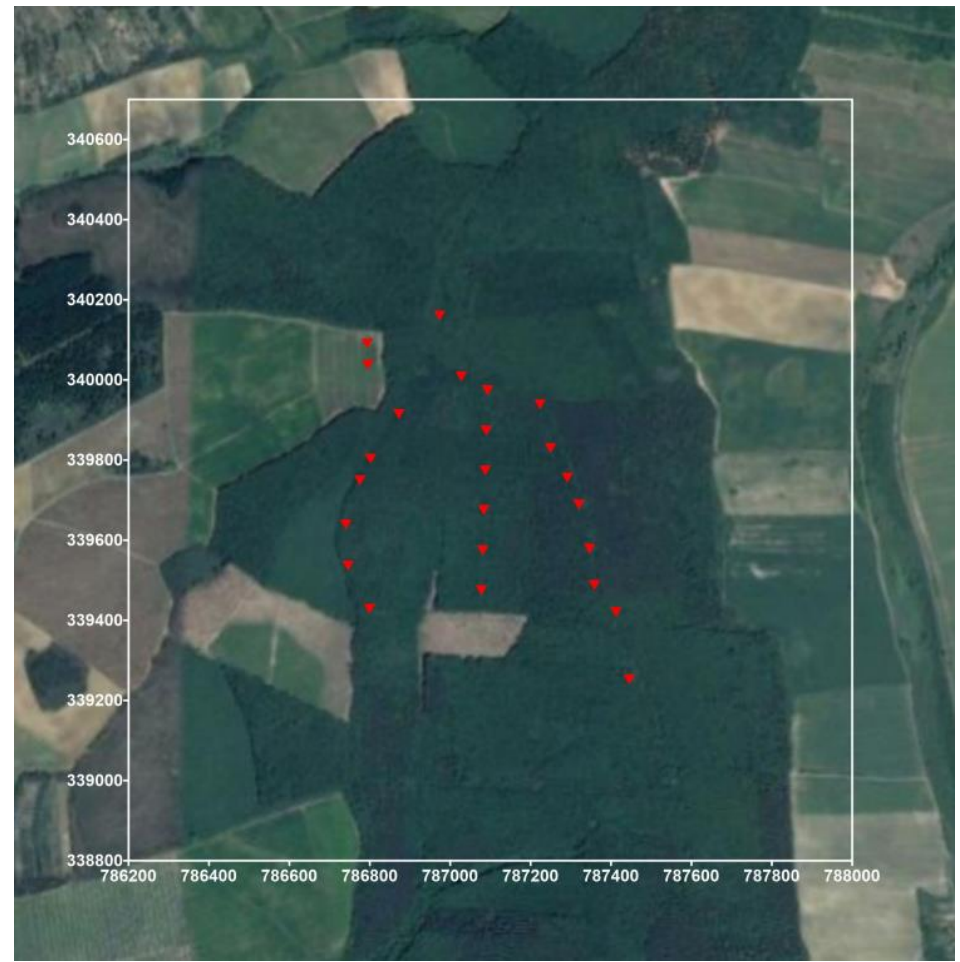

1. ábra. Az irotai kutatási terület müholdképe az EOV koordináták és az MT állomások feltüntetésével.

A mérési terület rétegsorában előforduló kőzeteket a paleozoós aljzat és az arra települő neogén üledékek alkotják. A devontól a miocénig tartó üledékhézag miatt mezozoós kőzetek nem fordulnak elő. 
A nyersanyagkutatás szempontjából a legjelentősebb geológia egység az Irotai Formáció, a területen a legidősebb ismert képződmény. Ebben található a fém-szulfid ásványokkal telített szakasz, mely feltehetően a mágneses anomáliát is okozza. Euxin medencefácies jellemző rá, fekete grafitfillit, kovapala, szürke metahomokkő és fehéresszürke mészfillit váltakozásából épül fel [2].

\section{Mérési módszerek}

Az irotai kutatási területről több felszíni geofizikai kutatómódszer eredményei is rendelkezésre állnak. Ezek közül megemlítendőek a gravitációs, mágneses, szeizmikus és magnetotellurikus mérések és azok eredményei. Ezen mérési eredmények összesítésére koncentrál jelen tanulmány. Egyenáramú geoelektromos VESZ szondázások is történtek a területen, melyek alapján a paleozoós aljzat morfológiáját sikerült pontosítani.

\subsection{Gravitációs kutatómódszer}

A gravitációs kutatómódszer Eötvös Loránd munkássága nyomán az első alkalmazott geofizikai módszernek tekinthető. Nyersanyagkutatásban elsősorban az előkutatási fázisban alkalmazzák, felbontóképessége relatíve gyenge, viszont aránylag olcsón gyüjthető vele a kőzetek sürüségeloszlására vonatkozó információ viszonylag nagy területről.

$\mathrm{Az} 5 \mathrm{pont} / \mathrm{km}^{2}$ sürüségü gravitációs alaphálózat adataiból $2200 \mathrm{~kg} / \mathrm{m}^{3}$ sürüséggel számolt Bougeranomália térkép és maradékanomália térképsorozat készült [1]. A gravitációs tér a Szendrői-hegység délkeleti peremétől észak felé (a paleozoós kibúvások felé) folyamatosan csökken. A pozitív anomáliát irotai gravitációs maximumvonulatnak is nevezik.

\subsection{Mágneses kutatómódszer}

Mágneses mérésekkel a Föld mágneses terét mérjük, mely a geomágneses térnek és a felszín alatti lokális mágneses hatók terének szuperpozíciójából áll elö. Természetesen egyéb felszíni hatások (zaj) is felléphetnek, ezek azonban a mérési adatokból kiszürhetőek.

Földmágneses anomália is ismertté vált a területen már az 1950-es években, melynek hatására később az érckutatás is megindult a környéken. A pontosabb lokalizálás érdekében 1986-ban a Bolgár Légigeofizikai Szolgálat végzett helikopteres gamma-spektrometriai és légimágneses méréseket. A mérés eredményeképpen egy mágneses hatótest lett meghatározva $\mathrm{k}=21,4 \quad 10^{-3}$ SI szuszceptibilitással. Ez részben egybeesik az irotai gravitációs maximumvonulattal [1].

Az ismertté vált irotai mágneses anomália pontosabb megismerése érdekében 2011-ben részletes felszíni mágneses mérések történtek a területen, $12 \mathrm{db}$ nyomvonalon, összesen $1625 \mathrm{db}$ mérési ponton [4]. A mérési adatok interpolációját követően $11 \mathrm{db}$ egymással párhuzamos, É-D-i irányú szelvény állt elö, melyeknek a 2D inverziós feldolgozása történt meg a mag2dc szoftverrel, valamint pólusra redukált mágneses anomáliatérkép készült.

\subsection{Szeizmika}

A területen $2 \mathrm{db}$ 2D reflexiós szeizmikus szelvény halad át, melyeket szintén az 1980-as években mértek. A NyDNy-KÉK csapású Sze-1 és az ÉNy-DK csapásirányú Sze-4 szelvények a Felsővadász-1 (FV-1) fúrás közelében metszik egymást. A Sze-4 szelvényen a FV-1 fúrás közelében egy vetőzóna értelmezhető. A nagyobb léptékű szeizmikus mérések, valamint a szerkezetföldtani kutatások figyelembevételével megállapítható, hogy a szerkezeti vonalak fö iránya NyDNy-KÉK. Feltehetően ezen 
vonalak mentén töredezhetett a paleozoós aljzat és süllyedt lépcsősen a mélybe [1]. Az aljzatmélység térkép és a gravitációs anomália térkép is alátámasztja ezt.

\subsection{Magnetotellurikus kutatómódszer}

A magnetotellurika (MT) passzív elektromágneses (EM) felszíni geofizikai kutatómódszer, melynek alkalmazásakor a primer és a szekunder EM tér összegének időbeli változását regisztráljuk a Föld felszínén. A szekunder tér a kőzetek fajlagos ellenállásának és geometriájának függvénye.

Az összesen 24 magnetotellurikus mérési állomás adatai három ciklusban, 2013 öszén, valamint 2014 tavaszán és őszén kerültek regisztrálásra (1. ábra). A 2013 őszi ciklusban a keleti MT-1 szelvény pontjainak (ir03-ir12), a tavaszi ciklusban a nyugati MT-2 szelvény pontjainak (ir22-ir29), végül 2014 öszén az MT-3 szelvény pontjainak (ir30-ir35) a felvételezése zajlott [5].

A legtöbb állomás esetében egy órán át zajlott a jelek regisztrálása (néhány állomás esetében 12 órás mintavételezés történt). Így a beérkező jelek a 0,1-1000 Hz-es tartományban lettek megmintázva. Az adatgyüjtés az MFGI Metronix GMS-06 típusú mérörendszerével történt. Ennek fő részét az ADU06 (Analog Digital Unit) elnevezesű adatgyüjtő egység képezi, melyhez az elektromos és a mágneses szenzorok közvetlenül csatlakoznak. A mesterséges elektromágneses zajforrásokat sikerült megfelelő távolságban (1-2 km) elkerülni, így azok nem zavarták a mérést.

A mérési pontok három szelvény mentén helyezkednek el, így az adatok elöször 2D MT inverzióval [6] lettek feldolgozva. Ennek eredményeit részletesen megtaláljuk Nádasi et. al. (2015) munkájában. Ezt követően az adatok 3D inverzióval is feldolgozásra kerültek Gribenko és Zhdanov (2017) inverziós kódjával [7], mely a regularizált Gauss-Newton eljárás adattérbeli implementációja.

\section{Különböző geofizikai mérési eredmények szintézise}

A 2. ábrán a fent részletezett kutatómódszerek és azok mérési eredményeinek együttes térképi megjelenítése látható. Az alaptérképi réteg az $550 \mathrm{~m}$ mélységre 3D MT inverzióval számított fajlagos ellenállás horizontális metszet. Azért ez a mélységszint került megjelenítésre, mivel ez már biztosan a paleozoós aljzat tartománya a mérési terület legnagyobb részén. Előzetesen az MT mérés célja az aljzaton belüli vezetőképes zónák kimutatása volt.

A melegebb színek jelölik az alacsonyabb, míg a hidegebb színek a magasabb fajlagos ellenállású térrészeket. Megfigyelhető, hogy két jól vezető (alacsony fajlagos ellenállású) zóna is kirajzolódik. További két hasonló zóna is látható a térkép ÉNY-i és ÉK-i részén, ám ezek kívül esnek az MT állomások hálózatán, ezért ezek kevésbé tekinthetők megbízható inverziós eredményeknek.

Mindkét zóna arra a területre esik, amelyen 50 nT-nál nagyobb mágneses anomália jelentkezik [8], ezt a területet kék szaggatott vonal jelöli. A halványabb színnel jelölt izovonalak szintén a pólusra redukált mágneses anomália értékét mutatják.

A térkép északi részén található zöld folytonos vonallal határolt terület a $25 \mathrm{mGal}$-nál nagyobb gravitációs anomáliát jelzi. Ez dél felé haladva fokozatosan csökken, ez összecseng azzal a modellel, hogy a paleozoós aljzat déli irányban egyre mélyebb helyzetbe kerül. Az aljzatot fedő neogén üledékek ugyanis kisebb sürüséggel jellemezhetőek.

A térképen a Felsővadász-1 (Fv-1), valamint a Sze-1 és Sze-4 reflexiós szeizmikus szelvények is jelölve vannak, melyek a területen jóval túlnyúlnak, viszont a Fv-1 fúrás közelében keresztezik egymást. A 2. ábra alapján a Fv-1 fúrás nem esik a legnagyobb mágneses, illetve vezetőképesség anomáliával rendelkező területekre. Ez a további kutatások szempontjából mindenképpen fontos megfigyelés. 


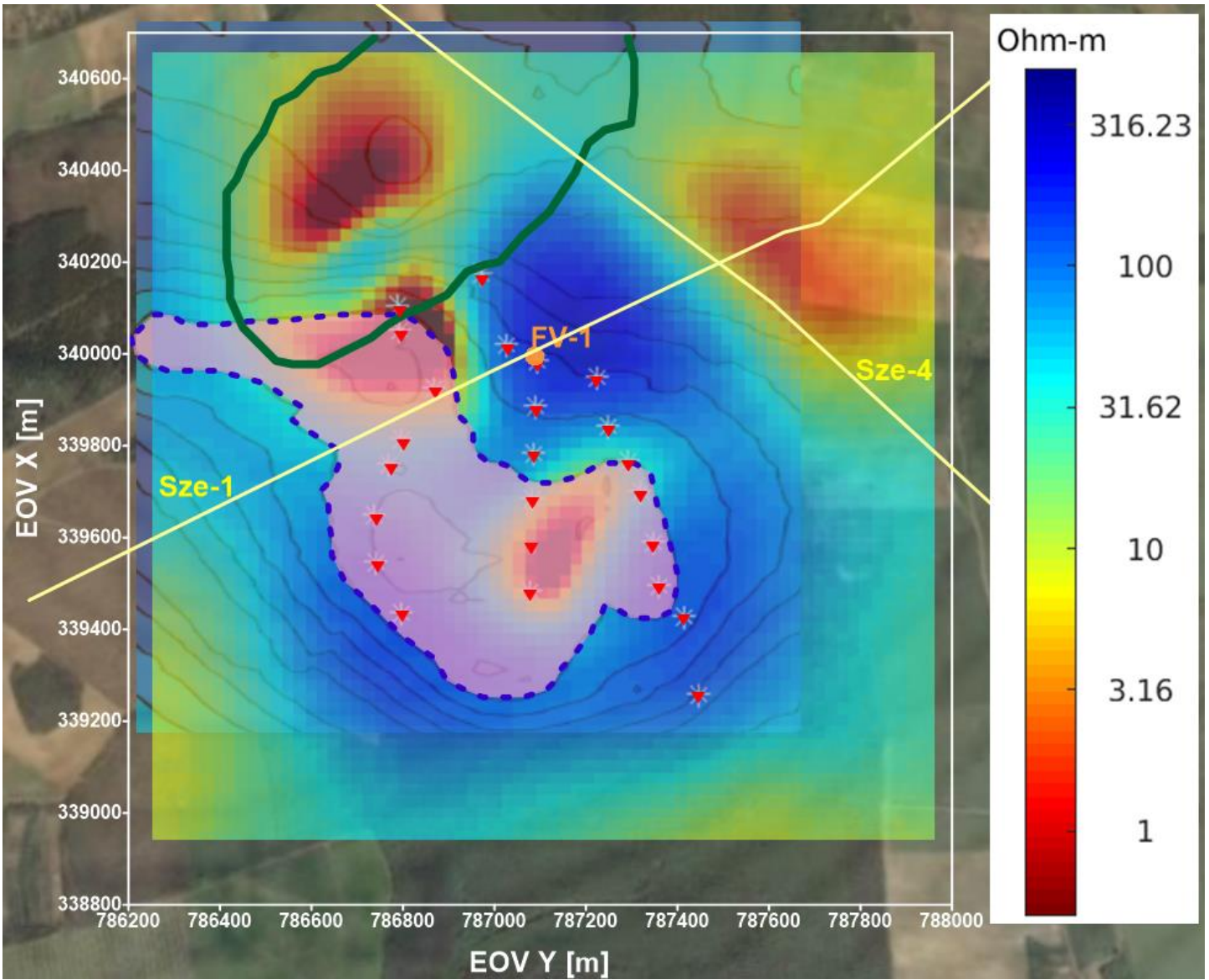

2. ábra. Az irotai kutatási terület müholdképe, rajta a 3D inverzióval kapott fajlagos ellenállás horizontális metszet 550 méter mélységben. A kék szaggatott vonal által határolt, rózsaszínnel szinezett terület a pólusra redukált mágneses térképen az 50 nT-nál nagyobb anomáliát jelöli [8]. A zöld folytonos vonal a $26 \mathrm{mGal-nál} \mathrm{nagyobb} \mathrm{gravitációs} \mathrm{anomáliát} \mathrm{határolja} \mathrm{[1].} \mathrm{Piros} \mathrm{háromszöggel} \mathrm{az} \mathrm{MT}$ állomások, narancssárga körrel a Felsövadász-1 (FV-1) fúrás, sárga folytonos vonalakkal a Sze-1 és Sze-4 reflexiós szeizmikus szelvények láthatók.

\section{5. Összefoglalás}

Következtetésként levonható, hogy a mágneses és a vezetőképesség anomália legalább részben egybeesik. Ez azzal magyarázható, hogy a szulfidos zóna csökkenti a fajlagos ellenállást, másrészt a pirrhotin jelenléte mágneses anomáliát okoz. A fúrásokban magas pirrhotintartalmú képződményeket írtak le, pedig a FV-1 fúrás nem esik a legnagyobb anomáliával jellemezhető zónák területére. Az alacsony fajlagos ellenállást emellett a grafitos zónák, illetve az egyéb hidrotermás átalakuláson átment kőzettestek is okozhatják. A gravitációs anomália feltehetőleg inkább az aljzatmélységre érzékeny, nem pedig az aljzatban kialakult hidrotermásan átalakult zónákra.

A geofizikai (mágneses, vezetőképesség) anomáliák mindenképp további részletes földtani kutatásra érdemesek. 


\section{Köszönetnyilvánítás}

A cikkben ismertetett kutató munka az EFOP-3.6.1-16-2016-00011 jelü „Fiatalodó és Megújuló Egyetem - Innovatív Tudásváros - a Miskolci Egyetem intelligens szakosodást szolgáló intézményi fejlesztése" projekt részeként - a Széchenyi 2020 keretében - az Európai Unió támogatásával, az Európai Szociális Alap társfinanszírozásával valósul meg.

\section{Irodalom}

[1] Szalai, I., Braun L., Petrovics I., Schőnvinszky L. és Zalai P.: Észak-Magyarország geofizikai előkutatása - Szendröi-hegység előkutatása, MÁELGI Évi Jel. 1987. pp. 35-39.

[2] Fülöp, J.: Magyarország geológiája, Paleozoikum II. Akadémiai Kiadó, Budapest, 1994.

[3] Földessy, J. és Németh, N.: Ritkaföldfémek a Cserehát néhány földtani képzödményében. 2014. In: CriticEl Monográfia Sorozat 5., Ritkaföldfémek magyarországi földtani képződményekben. Szerk.: Szakáll S.

[4] Czeglédi, B.: Mágneses mérések a Szendröi-hegységben, egy érctest múltbeli kialakulásának nyomozása, 2011. TDK Dolgozat. Miskolci Egyetem.

[5] Nádasi E., Madarasi, A., Turai E.: Magnetotelluric exploration in the vicinity of Irota and Gadna, Geosciences and Engineering. A Publication of the University of Miskolc 4:6, pp. 105-115. 2015.

[6] Rodi, W. és Mackie, R.L.: Nonlinear conjugate gradients algorithm for 2-D magnetotelluric inversion, Geophysics, 66, 174-187., 2001. https://doi.org/10.1190/1.1444893

[7] Gribenko, A. V. és Zhdanov, M. S.: MT3D ver. 2017, Release March 2018.

[8] Kiss, J.: Magyarország 100 000-es geofizikai térképsorozata, Mágneses DT térkép, 98. térképlap (Encs), ELGI, 2001. 